\title{
Day and Night Feeding in Dunlins Calidris alpina: Choice of Habitat, Foraging Technique and Prey
}

\author{
K. N. Mouritsen \\ Journal of Avian Biology, Vol. 25, No. 1. (Mar., 1994), pp. 55-62.
}

Stable URL:

http://links.jstor.org/sici?sici=0908-8857\%28199403\%2925\%3A1\%3C55\%3ADANFID\%3E2.0.CO\%3B2-V

Journal of Avian Biology is currently published by Nordic Society Oikos.

Your use of the JSTOR archive indicates your acceptance of JSTOR's Terms and Conditions of Use, available at http://www.jstor.org/about/terms.html. JSTOR's Terms and Conditions of Use provides, in part, that unless you have obtained prior permission, you may not download an entire issue of a journal or multiple copies of articles, and you may use content in the JSTOR archive only for your personal, non-commercial use.

Please contact the publisher regarding any further use of this work. Publisher contact information may be obtained at http://www.jstor.org/journals/oikos.html.

Each copy of any part of a JSTOR transmission must contain the same copyright notice that appears on the screen or printed page of such transmission.

The JSTOR Archive is a trusted digital repository providing for long-term preservation and access to leading academic journals and scholarly literature from around the world. The Archive is supported by libraries, scholarly societies, publishers, and foundations. It is an initiative of JSTOR, a not-for-profit organization with a mission to help the scholarly community take advantage of advances in technology. For more information regarding JSTOR, please contact support@jstor.org. 


\title{
Day and night feeding in Dunlins Calidris alpina: choice of habitat, foraging technique and prey
}

\author{
K. N. Mouritsen
}

Mouritsen, K. N. 1994. Day and night feeding in Dunlins Calidris alpina: choice of habitat, foraging technique and prey. - J. Avian Biol. 25: 55-62.

\begin{abstract}
The diurnal and nocturnal foraging behaviour of Dunlins Calidris alpina was investigated during their autumn migration in the Danish Wadden Sea. Dunlins fed regularly by both day and night. However, they tended to utilize different habitats during daytime and night-time, with relatively more birds aggregating on soft sediment containing high densities of Corophium volutator at night. Pecking was the dominant foraging technique during the daytime, whereas probing was the preferred technique at night. Dropping analysis revealed quantitative differences between the birds' diurnal and nocturnal diets. It is proposed that nocturnal foraging may be important for restoring fat deposits in migrating birds.
\end{abstract}

K. N. Mouritsen, Institute of Biological Sciences, Department of Ecology and Genetics, University of Aarhus, Ny Munkegade build. 540, DK-8000 Aarhus C, Denmark.

Nocturnal foraging in shorebirds has frequently been reported (Goss-Custard 1984, Burger 1984, Manseau and Ferron 1991, see McNeil et al. in press for details). However, because of the obvious difficulties in obtaining detailed observations during darkness, little is known about the relative importance of night-feeding or the particular techniques involved. Night-feeding has been reported for wintering shorebirds in English estuaries and, recently, from tropical environments (Robert and McNeil 1989, Robert et al. 1989, McNeil et al. in press). In these areas, night-feeding is mainly thought to compensate for insufficient energy intake during daylight, either because of low temperatures and short day-lengths in temperate latitudes in winter (Goss-Custard 1969, Heppleston 1971, GossCustard et al. 1977, Pienkowski 1981,1982 , Puttick 1984), or low prey availability because of desiccation of the substrate in the tropics (Engelmore et al. 1984, McNeil et al. in press). Increased prey availability at night is also considered to promote a preference for night-feeding (Dugan 1981, Pienkowski 1983a, Evans 1987, McNeil and Robert 1988). During migration periods, night-feeding may be connected with deposition of body fat (Batty 1988, Zwarts et al. 1990, Morrier and McNeil 1991).

Occasionally, shorebirds utilize different foraging sites by day and night, this being explained by changed prey availability or vulnerability to predators (Townshend et al. 1984, Roberts et al. 1989). Feeding techniques may also differ between day and night. A switch from visual searching by day to more tactile prey detection at night is the usual pattern (Goss-Custard 1970, Hulscher 1976, Robert and McNeil 1989). Such differential use of habitats and feeding mode might be expected to affect the birds' diurnal and nocturnal diets, but this aspect is presently poorly known (see Robert and McNeil 1989).

During migration, Dunlins Calidris alpina are the most abundant shorebird species in the Danish Wadden Sea (Laursen and Frikke 1984). To achieve a more complete picture of the birds' impact on this ecosystem their nocturnal behaviour has to be known. The present paper report on the Dunlins' diurnal and nocturnal preference for habitat, foraging technique and prey.

\section{Materials and methods}

\section{Study area}

The study was carried out at Højer tidal flat in the southern part of the Danish Wadden Sea $\left(54^{\circ} 56^{\prime} \mathrm{N}, 8^{\circ} 39^{\prime} \mathrm{E}\right)$ in

(C) JOURNAL OF AVIAN BIOLOGY 
September and October 1989. Two transects, each $100 \mathrm{~m}$ wide and $400 \mathrm{~m}$ apart, were established perpendicular to the coastline on a homogeneous mudflat $(1500 \mathrm{~m}$ intertidal zone) and across a well-developed Corophiumbed (Reise 1978), respectively. The Corophium-bed was situated in the upper intertidal zone expanding from MHWL (mean high water level) to $800 \mathrm{~m}$ seaward, and which at low water comprised alternating emerged areas and pools. Four sites on the mudflat $(400,600,800$ and $1000 \mathrm{~m}$ from MHWL), and two sites on the Corophiumbed (400 and $600 \mathrm{~m}$ from MHWL), each 1 ha, were chosen as sampling and census sites.

\section{Bird counts}

The density of foraging Dunlins was recorded on all sites at maximum low water $( \pm 1 \mathrm{~h})$ during nine diurnal and nine nocturnal low tides. During daytime, the birds were observed using a telescope $(\times 25)$, whereas at night a Zeiss Orion image-intensifier (intensifying capacity > $40,000 \times$ ) or a lamp to highlight the birds (on dark nights) was used. Brief illumination did not affect the birds in any notable manner. To ascertain whether Dunlins were feeding at night also outside the main study site, three other sites scattered along the $5 \mathrm{~km}$ shoreline were regularly visited during nocturnal low tides to determine the presence or absence of feeding Dunlins.

The overall population of Dunlins feeding at Højer tidal flat was estimated by counts along the $5 \mathrm{~km}$ shoreline about $1 \mathrm{~h}$ before maximum low water. On two occasions (around full moon and new moon), the tide receded at sunset. This made it possible to estimate the population of feeding Dunlins at the tide edge prior to a nocturnal low tide period and compare these figures with daytime records obtained a few days later.

\section{Foraging technique}

The Dunlins' diurnal and nocturnal foraging techniques were investigated on the Corophium-bed at maximum low water $( \pm 1.5 \mathrm{~h})$ on two days, two moonlit nights (full moon), and one dark night (half moon, clouded). Total sampling time was 327 minutes. The foraging behaviour of individual birds was observed over periods of usually 1 min using the telescope by day and the image-intensifier at night, and the observations were tape-recorded. The observed birds were observed ad libitum as they entered the field of vision. Feeding attempts and paces were recorded separately since the birds' fast-moving behaviour made simultaneous observations difficult. Foraging attempts were assigned to one of four categories: pecks (the bill inserted $0-1 \mathrm{~cm}$ into the sediment), intermediate probes (bill half inserted; $1-2 \mathrm{~cm}$ ), deep probes (entire bill inserted; $2-3 \mathrm{~cm}$ ), and drilling (probing several times at the same site), the latter being analyzed as a single feeding event. Because the proportion of deep probes may increase as the intertidal flat dries up (see Boates and Smith 1989), observations were evenly scattered throughout the observation period to avoid biased data. No attempt was made to measure the Dunlins' foraging success directly.

\section{Dropping analysis}

Pellets regurgitated by Dunlins were never found in the study area. Faecal droppings were therefore collected to examine the Dunlins' choice of prey. Droppings were sampled in pools of 20 , and subsequently stored in $80 \%$ ethanol. Diurnal and nocturnal collection was conducted on both transects around the time of full moon and half moon (clouded). On the bed, identification of droppings was straightforward since the Dunlins were the only sandpipers present prior to collection. The presence of some Ringed Plovers Charadrius hiaticula on the mudflat, particular at night, made it necessary to follow the Dunlins closely to ensure that the correct droppings were collected. As this procedure proved to be difficult on dark nights, night faeces were sampled only on moonlit nights on the mudflat.

The samples were analyzed in the laboratory using a stereomicroscope. Prey species were identified by means of mandibles, acicules, chetae, and tubes (Polychaeta); shell fragments (Molluscs); exoskeletons and setae (Crustaceans); scales (Pisces). The fragments were quantified in the case of molluscs (no. of shell fragments), crustaceans (no. of exoskeleton fragments) and Nereis diversicolor (no. of mandibles and acicules). To identify smaller chetae and setae, a subsample was withdrawn from each bulk sample and analyzed under a light microscope.

According to Worrall (1984), dropping analysis is not recommendable if the relative importance of various prey items has to be evaluated. Obviously, droppings contain only indigestible material, and soft-bodied prey items without conspicuous hard parts (e.g., oligochaets and amphipods) may be seriously underestimated. Furthermore, most indigestible fragments are voided orally, and only the smaller fragments pass into the droppings, so causing the quantification of hard parts to be biased (Worrall 1984). It is, however, reasonable to expect a positive relationship between the number of a specific prey species ingested and the amount of indigestible hard parts passing into the droppings. So, as long as hard parts are quantified to determine the relative importance of a certain prey between different areas or at different times the approach should be valid.

\section{Invertebrate sampling}

To determine the density of infaunal prey, 5-10 sediment cores $\left(50 \mathrm{~cm}^{2}, 25 \mathrm{~cm}\right.$ deep) were collected randomly at each study site. Samples were sieved in the field through 
Fig. 1. Density of foraging Dunlins during daytime and night-time at the study site. Mean numbers per ha $( \pm$ $\mathrm{SE})$ at low water are given. (A) The mudflat $(\mathrm{n}=9)$, (B) the Corophium-bed $(\mathrm{n}=8)$. Light and dark bars denote densities at diurnal and nocturnal low tides, respectively. MHWL = mean high water level.
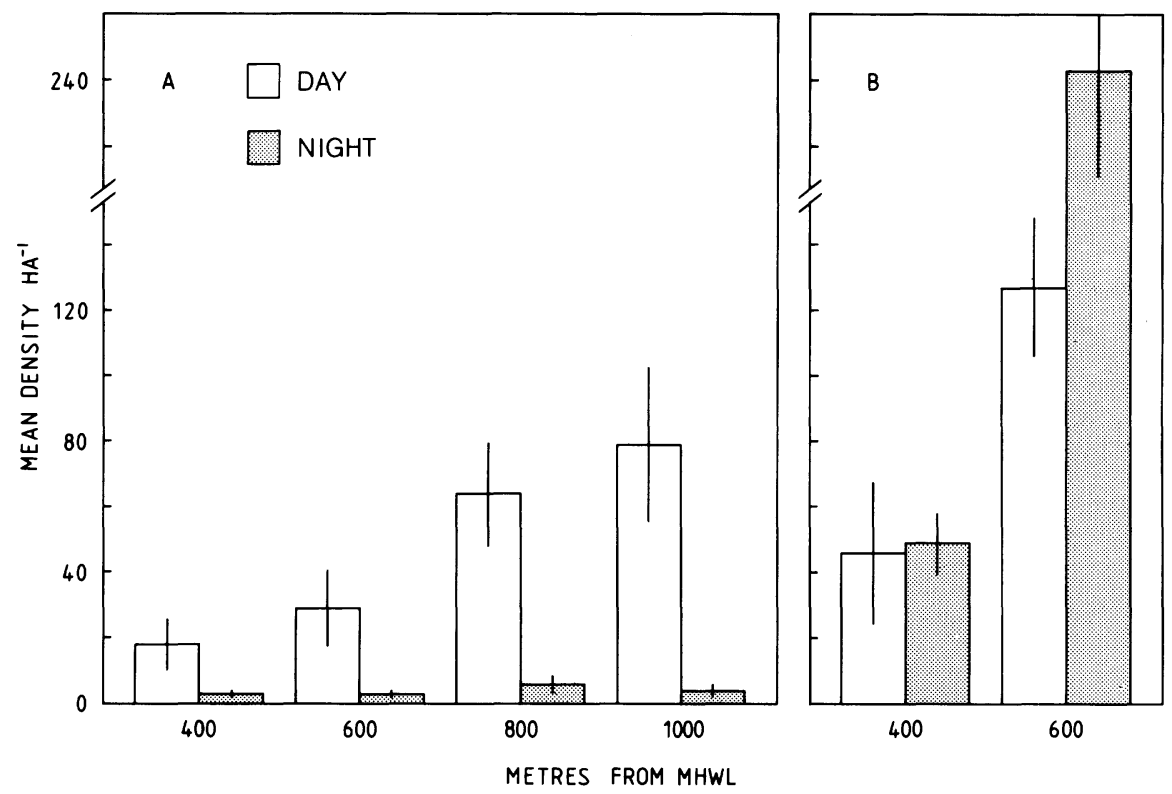

a $500 \mu \mathrm{m}$ mesh and retained organisms were fixed in $10 \%$ formalin.

The diurnal and nocturnal surface activity of invertebrates was recorded on the Corophium-bed $(600 \mathrm{~m}$, emerged areas) and on the mudflat $(800 \mathrm{~m})$ at maximum low water. The number of individuals present at the surface within either a $0.01 \mathrm{~m}^{2}, 0.04 \mathrm{~m}^{2}$ or $0.16 \mathrm{~m}^{2}$ frame (depending on the density of the species involved) were counted in ten plots at each site. In addition, the sediment (at $1 \mathrm{~cm}$ depth) and air temperatures were measured. Specimens of Corophium volutator crawling on the sediment surface were collected on the Corophium-bed (600 $\mathrm{m}$, emerged areas) at maximum low water during three diurnal and three nocturnal low tides. The animals were stored in $10 \%$ formalin and their length (rostrum to telson) measured in the laboratory. Since almost equal numbers were collected at each low tide, the diurnal and nocturnal size distributions of surface active Corophium specimens obtained are based on pooled data.

In order to determine the diurnal and nocturnal availability of Corophium to the Dunlins, a "sample-sledge" was used to plane off the upper sediment strata. The sledge was pushed over the substrate (speed about $1 \mathrm{~m}$ $\mathrm{s}^{-1}$ ), at a distance of c. $1.5 \mathrm{~m}$ from the user, thereby giving tube-dwelling animals minimal time to react to the disturbance. At the end of each track, the sledge contained the last $100 \mathrm{~cm}^{2}$ of the sediment that was planed off. On two consecutive low tides, one diurnal and one nocturnal, five $1.5 \mathrm{~cm}$ deep and five $3.0 \mathrm{~cm}$ deep sledge samples were collected at maximum low water on the Corophium-bed (600 m, emerged areas) and treated as the other sediment samples collected.

\section{Sediment analysis}

Since the softness of the substrate is known to affect the distribution and foraging behaviour of shorebirds (Tjallingii 1972, Myers et al. 1980, Grant 1984, Kelsey and Hassall 1989, Mouritsen and Jensen 1992), the penetrability of the sediment was recorded on both transects $(600 \mathrm{~m}$ on the Corophium-bed (emerged areas and pools); $400-1000 \mathrm{~m}$ on the mudflat) by using a penetrometer of own design. A conical steel $\operatorname{rod}(12.0 \mathrm{~cm}$ long, $0.2-1.0 \mathrm{~cm}$ diameter, $61.3 \mathrm{~g}$ ) with scale markings was dropped from a standard height $(180 \mathrm{~cm})$ through a tube mounted on a stand. Penetrability was measured as the distance $(\mathrm{cm})$ the rod penetrated the sediment.

\section{Results}

\section{Distribution of foraging Dunlins}

During all diurnal and nocturnal low tide periods in which the intertidal zone was visited, Dunlins were present in the main study area as well as on the other sites inspected. Records of birds feeding at Højer tidal flat at dusk prior to nocturnal low tides were roughly similar to those records obtained during diurnal low tides. At full moon c. 34,800 Dunlins were feeding at dusk compared with c. 41,350 in the daytime. At new moon, the figures were c. 23,650 and c. 26,450 , respectively. Because birds feeding at dusk continued to do so after dark on all sites inspected, these observations suggest that the foraging activity by day and by night is of the same order of magnitude.

The diurnal and nocturnal densities of foraging Dunlins were different on the two transects (Fig. 1). Two-way 
Table 1. The foraging behaviour of Dunlins during daytime, moonlit nights (full moon), and a dark night (half moon, clouded). Values are means $( \pm S E)$ [no. of birds observed]. Intervals of $\mathrm{cm}$ indicate the depth to which the bill was inserted. P: Normal approximated Wilcoxon two-sample test. ns = non-significant $(\mathrm{P}>0.1)$, ${ }^{*} \mathrm{P}<0.01$, $* * * \mathrm{P}<0.001$. The difference between daylight and the dark night is significant at least on the $5 \%$ level if not otherwise indicated.

\begin{tabular}{|c|c|c|c|c|c|}
\hline Behaviour & Day & $\mathrm{P}$ & $\begin{array}{c}\text { Night } \\
\text { (Moonlight) }\end{array}$ & $\mathrm{P}$ & $\begin{array}{l}\text { Night } \\
\text { (Dark) }\end{array}$ \\
\hline Peck/probe s ${ }^{-1}$ & $1.1(0.1)$ [40] & $* * *$ & $1.5(0.1)[28]$ & $* *$ & $1.7(0.1)[62]$ \\
\hline$\%$ Peck $(0-1 \mathrm{~cm})$ & $66.4(2.8)$ & $* *$ & $55.2(1.5)$ & $* * *$ & $40.0(2.3)$ \\
\hline Probe $(1-2 \mathrm{~cm})$ & 20.5 (1.4) & ns & $\begin{array}{c}17.9(1.3) \\
\mathrm{ns} \\
\end{array}$ & ns & $16.7(0.8)$ \\
\hline Probe $(2-3 \mathrm{~cm})$ & $12.6(2.0)$ & $* * *$ & $26.3(1.0)$ & $* * *$ & $41.6(2.2)$ \\
\hline Drilling & $0.6(0.3)$ & ns & $0.8(0.2)$ & ns & $1.8(0.5)$ \\
\hline Pace $\mathrm{s}^{-1}$ & $2.4(0.1)[34]$ & $* * *$ & $\begin{array}{r}3.0(0.1)[33] \\
\end{array}$ & $* *$ & $2.4(0.1)[62]$ \\
\hline
\end{tabular}

ANOVA performed on ln-transformed data (to obtain homogeneity of variance) showed that bird densities on the mudflat were significantly higher by day than at night $\left(F_{1,70}=22.68, P<0.001\right.$, Fig. 1A). In contrast, densities on the Corophium-bed were significantly higher at night than in daytime $\left(F_{1,30}=5.79, P=0.023\right.$, Fig. 1B). Comparison of all sites using one-way ANOVA followed by a SNK-test revealed that the Corophium-bed at night supported considerably more birds than any site on the mudflat $\left(\mathrm{F}_{5,46}=43.76, \mathrm{P}<0.001\right.$; SNK-test, $\left.\mathrm{P}<0.05\right)$. During daytime, however, the pattern was less clear. The density at $600 \mathrm{~m}$ on the Corophium-bed was significantly higher than at all other sites $\left(\mathrm{F}_{5,46}=4.82, \mathrm{P}=0.001\right.$; SNK-test, $\mathrm{P}$
$<0.05$ ), whereas no difference could be demonstrated among the sites on the mudflat and at $400 \mathrm{~m}$ on the Corophium-bed (SNK-test, P > 0.05). Estimation of birdminutes on the two transects during a few diurnal and nocturnal low tide periods were in general agreement with the above distribution pattern (see Mouritsen 1991).

\section{Foraging technique}

The Dunlins' foraging rate (pecks or probes per second) was significantly higher on the dark night than in daytime (Table 1). Pecking was the predominant feeding tech-

Table 2. The Dunlins' diurnal and nocturnal diets. Values are mean number of prey fragments found in bulk samples of faecal droppings $(\mathrm{n}=20)$. + denotes that the species is identified but not quantified. $\mathrm{P}: \mathrm{ns}=$ non-significant $(\mathrm{P}>0.1),{ }^{*} \mathrm{P}<0.05, * * \mathrm{P}<0.01$ by Mann-Whitney test.

\begin{tabular}{|c|c|c|c|c|c|c|c|c|}
\hline \multirow[t]{2}{*}{ Species } & \multicolumn{3}{|c|}{ Corophium-bed } & \multicolumn{3}{|c|}{ Mudflat } & \multirow[b]{2}{*}{$\mathrm{P}^{1}$} & \multirow[b]{2}{*}{$\mathrm{P}^{2}$} \\
\hline & Day & Night & $\mathrm{P}$ & Day & Night & $\mathrm{P}$ & & \\
\hline \multicolumn{9}{|l|}{ Polychaeta } \\
\hline Nereis diversicolor & 4.3 & 7.4 & $* *$ & 15.6 & 17.6 & ns & $* *$ & $* *$ \\
\hline Nephtys spp. & 0 & 0 & - & + & 0 & - & - & - \\
\hline Phyllodocids & 0 & 0 & - & + & + & - & - & - \\
\hline Spionids & 0 & + & - & + & 0 & - & - & - \\
\hline Arenicola marina & 0 & 0 & - & + & 0 & - & - & - \\
\hline \multicolumn{9}{|l|}{ Gastropoda } \\
\hline Hydrobia ulvae & 37.5 & 11.9 & $* *$ & 43.8 & 10.4 & $* *$ & ns & ns \\
\hline Retusa obtusa & + & + & - & 0 & 0 & - & - & - \\
\hline \multicolumn{9}{|l|}{ Bivalvia } \\
\hline Macoma balthica/Mya arenaria & 14.1 & 14.9 & ns & 31.5 & 25.9 & ns & $* *$ & * \\
\hline Cerastoderma edule & 5.7 & 4.1 & ns & 24.3 & 31.4 & ns & $* *$ & $* *$ \\
\hline \multicolumn{9}{|l|}{ Crustaceans } \\
\hline Carcinus maenas & 0 & 0 & - & 2.4 & 0 & $*$ & $*$ & - \\
\hline Corophium spp. & 1.6 & 4.0 & $* *$ & 0.9 & 1.1 & ns & ns & $* *$ \\
\hline Pisces & + & 0 & - & + & 0 & - & - & - \\
\hline No. of bulk samples analyzed & 16 & 18 & & 20 & 7 & & & \\
\hline
\end{tabular}

\footnotetext{
${ }^{1,2}$ Comparison between the mudflat and the Corophium-bed by day ${ }^{1}$ and at night ${ }^{2}$.
} 
Table 3. The densities of the most relevant invertebrate prey species on the Corophium-bed (600 m) and on the mudflat. Values are mean number per $50 \mathrm{~cm}^{2}( \pm \mathrm{SE})$. Densities were compared using one-way ANOVA (ns = non-significant, $\mathrm{P}>0.05, * \mathrm{P}<0.05, * * \mathrm{P}<$ $0.01, * * * \mathrm{P}<0.001)$, followed by an SNK-test. Underlined values are not significantly different $(\mathrm{P}>0.05)$. Data analysis was performed on $\ln (x+1)$ transformed data to ensure homogeneity of variance $(P>0.05)$.

\begin{tabular}{|c|c|c|c|c|c|c|c|}
\hline \multirow[t]{2}{*}{ Species } & \multicolumn{2}{|c|}{ Corophium-bed } & \multicolumn{4}{|c|}{ Mudflat } & \multirow[t]{2}{*}{$\mathrm{P}$} \\
\hline & $\begin{array}{l}\text { Emerged area } \\
\quad(n=10)\end{array}$ & $\begin{array}{l}\text { Pools } \\
(n=6)\end{array}$ & $\begin{array}{c}400 \mathrm{~m} \\
(\mathrm{n}=10)\end{array}$ & $\begin{array}{l}600 m \\
(n=5)\end{array}$ & $\begin{array}{c}800 \mathrm{~m} \\
(\mathrm{n}=10)\end{array}$ & $\begin{array}{l}1000 m \\
(n=5)\end{array}$ & \\
\hline \multicolumn{8}{|l|}{ Polychaeta } \\
\hline Phylodoce maculata & $\underline{0.1(0.1)}$ & 0 & 0 & $0.2(0.2)$ & $0.4(0.2)$ & $1.2(0.6)$ & ** \\
\hline Nereis diversicolor & $1.2(0.4)$ & $\underline{0.6(0.2)}$ & $0.3(0.2)$ & $0.6(0.3)$ & $0.1(0.1)$ & $0.6(0.3)$ & $*$ \\
\hline Pygospio elegans & $2.4(1.3)$ & $0.8(0.4)$ & $13.6(2.5)$ & $\underline{4.2(0.7)}$ & $5.8(1.1)$ & $5.8(1.5)$ & $* * *$ \\
\hline \multicolumn{8}{|l|}{ Mollusca } \\
\hline Hydrobia ulvae & $35.9(3.6)$ & $124.0(15.7)$ & $57.2(3.1)$ & $131.8(11.8)$ & $88.1(5.2)$ & $\underline{150.8(28.5)}$ & $* * *$ \\
\hline Cerastoderma edule & $\underline{0.4(0.2)}$ & $0.3(0.2)$ & & $0.8(0.4)$ & $1.7(0.4)$ & $3.4(0.9)$ & $* * *$ \\
\hline Macoma balthica & $0.9(0.4)$ & $\underline{2.5(0.5)}$ & $2.7(0.4)$ & $3.0(0.5)$ & $2.5(0.4)$ & $2.0(0.6)$ & $* *$ \\
\hline Mya arenaria & $1.1(0.5)$ & $1.5(0.9)$ & $0.1(0.1)$ & $0.2(0.2)$ & $1.8(0.7)$ & $1.0(0.5)$ & ns \\
\hline \multicolumn{8}{|l|}{ Amphipoda } \\
\hline Corophium volutator & $589.4(9.0)$ & $46.7(12.3)$ & $0.1(0.1)$ & 0 & 0 & 0 & $* * *$ \\
\hline
\end{tabular}

nique in daylight, whereas deep probing was considerably more important in darkness, especially on the dark night. For all types of behaviour, except pace rate and proportion of intermediate probes, the Dunlins' foraging behaviour on moonlit nights occupied an intermediate position between daytime and the dark night.

At night, two rather distinct types of foraging behaviour occurred: a fast-moving pecking type, and a slowmoving probing type. An individual bird could perform these behaviours consecutively. Another notable feature of the Dunlins' nocturnal foraging behaviour was the occurrence of "double-pecks" made almost exclusively by the fast-moving birds. Such double-pecks were extremely rare in day-feeding birds regardless of a high peck rate.

\section{Choice of prey}

The Dunlins' diurnal and nocturnal diet is summarized in Table 2. Data from full and half moon periods are pooled, as no significant difference was found among quantified prey species (Mann-Whitney test, $\mathrm{P}>0.05$ ). H. ulvae and Carcinus maenas were more important prey by day than by night at the mudflat, whereas the other quantified species seemed equally important by day and night. On the Corophium-bed, H. ulvae was again more important during the daytime, while both $N$. diversicolor and $\mathrm{Co}$ rophium were more important at night. The comparison between the two transects shows that bivalves and $N$. diversicolor comprised a larger part of the diet on the mudflat than on the Corophium-bed both by day and by night. In contrast, Corophium was more important on the Corophium-bed than on the mudflat, but only at night. In the daytime samples, no significant difference was found between the two areas. Analysis of droppings (light mi- croscopy) revealed that all diurnal as well as nocturnal bulk samples from the Corophium-bed contained immense amounts of Corophium setae compared with those from the mudflat. Although these setae were not quantified, this obvious difference suggests that $C$. volutator is an important prey item when the Dunlins feed at the Corophium-bed, regardless of illumination level. Inclusion of more droppings in each bulk sample is required if softbodied amphipods are to be quantified reliably by fragments of exoskeletons.

\section{Prey density and availability}

The main difference between the Corophium-bed and mudflat was the dominance of the amphipod Corophium volutator on the former (about $118,000 \mathrm{~m}^{-2}$ on emerged areas), whereas polychaete worms (except Nereis diversicolor) and molluscs tended to be most abundant on the mudflat (Table 3 ). The population of $C$. volutator found on the Corophium-bed comprised mainly younger individuals (median length: $2.8 \mathrm{~mm}$; range: $1.3-8.6 \mathrm{~mm} ; \mathrm{n}=$ 1150). A comparison between the population density obtained by ordinary core samples and by the sledge samples (divided by two to obtain the sampling area of the corers) showed that $89.3 \%$ of the Corophium population were within the Dunlins' reach (the top $3 \mathrm{~cm}$ of the sediment) during the daytime, and $92.4 \%$ at night. No significant difference between day and night could be demonstrated (two-tailed $\mathrm{z}$-test, $\mathrm{z}_{\mathrm{c}}=1.85, \mathrm{P}>0.05$ ). However, the proportion of the population present in the upper $1.5 \mathrm{~cm}$ of the substrate was greater at night $(69.8 \%)$ than by day $(48.6 \%)\left(\mathrm{z}_{\mathrm{c}}=7.34, \mathrm{P}<0.001\right)$, and comprised significantly larger individuals at night (median $2.8 \mathrm{~mm}$; range: $1.3-7.8 \mathrm{~mm} ; \mathrm{n}=121$ ) than by day (median $2.2 \mathrm{~mm}$; range: $1.3-8.2 \mathrm{~mm} ; \mathrm{n}=139$ ) (Kolmo- 
Table 4. The diurnal and nocturnal surface activity of Phylodoce maculata, Corophium volutator and Hydrobia ulvae encountered on the sediment surface of the Corophium-bed (emerged area, $600 \mathrm{~m})$ and the mudflat $(800 \mathrm{~m})$ at low water. Values are mean number per sample area $(n=10)$. Values in () are $95 \% \mathrm{CI}$, whereas values in [ ] show asymmetric 95\% CL for $\log (\mathrm{x}+1)$ transformed data. The proportion of the population (Table 1) which constitutes the surface active individuals is also given. $\mathrm{N}$ and $\mathrm{F}$ denote the dates of new and full moon, respectively. Temperature measurements were carried out only on the bed when both areas were censused.

\begin{tabular}{|c|c|c|c|c|c|c|c|}
\hline & \multirow[b]{2}{*}{ Date } & \multicolumn{2}{|c|}{ Corophium-bed } & \multicolumn{2}{|c|}{ Mudflat } & \multicolumn{2}{|c|}{ Temperature $\left({ }^{\circ} \mathrm{C}\right)$} \\
\hline & & Corophium & Hydrobia & Phylodoce & Hydrobia & air & sediment \\
\hline Day & $\begin{array}{l}13 \text { Sep } \\
23 \text { Sep } \\
24 \text { Sep } \\
25 \text { Sep N }\end{array}$ & $\begin{array}{c}0.6[0-1.0] \\
1.0(0.5) \\
0 \\
0.4[0-0.7]\end{array}$ & $\begin{array}{c}22.3(3.7) \\
13.2(1.4) \\
7.9(1.9) \\
4.3(2.2)\end{array}$ & $\begin{array}{c}0 \\
0.1[0-0.2] \\
0\end{array}$ & $\begin{array}{l}45.3(2.3) \\
37.0(4.3) \\
41.1(3.8)\end{array}$ & $\begin{array}{l}15.5 \\
19.0 \\
16.2 \\
13.2\end{array}$ & $\begin{array}{l}15.3 \\
18.9 \\
20.0 \\
13.7\end{array}$ \\
\hline \multicolumn{2}{|c|}{$\%$ of population } & $<0.1$ & $6-31$ & $0-3$ & $21-26$ & & \\
\hline Night & $\begin{array}{l}15 \text { Sep F } \\
19 \text { Sep } \\
23 \text { Sep } \\
25 \text { Sep }\end{array}$ & $\begin{array}{l}3.1(1.6) \\
1.0(0.7) \\
3.2(0.9) \\
1.3(0.9)\end{array}$ & $\begin{array}{l}12.0(1.1) \\
32.0(5.3) \\
20.1(2.1) \\
15.2(2.4)\end{array}$ & $\begin{array}{c}0.6[0.1-1.0] \\
0.9(0.7) \\
0.4[0-0.7]\end{array}$ & $\begin{array}{l}24.8(5.7) \\
21.8(2.8) \\
26.8(4.1)\end{array}$ & $\begin{array}{l}12.9 \\
16.9 \\
14.3 \\
12.0\end{array}$ & $\begin{array}{l}13.0 \\
15.1 \\
13.6 \\
11.8\end{array}$ \\
\hline \multicolumn{2}{|c|}{$\%$ of population } & $<0.2$ & $17-45$ & $13-28$ & $12-15$ & & \\
\hline \multicolumn{2}{|c|}{ Sample area $\left(\mathrm{m}^{2}\right)$} & 0.16 & 0.01 & 0.04 & 0.01 & & \\
\hline
\end{tabular}

gorov-Smirnov test, $\mathrm{D}=0.30, \mathrm{P}<0.001)$. C. volutator individuals crawling at the sediment surface during low water were larger at night than by day (KolmogorovSmirnov test, $\mathrm{D}=0.32, \mathrm{P}<0.001$ ), the median lengths being $5.0 \mathrm{~mm}$ (range: $2.1-8.3 ; \mathrm{n}=130$ ) by day and 6.2 $\mathrm{mm}$ (range: $1.6-8.5 \mathrm{~mm} ; \mathrm{n}=122$ ) at night.

Of surface active species, only the polychaete Phylodoce maculata, the mudsnail Hydrobia ulvae and Corophium volutator occurred in numbers suitable for enumeration. On the Corophium-bed, no difference was found between the diurnal and nocturnal surface activity of $H$. ulvae, whereas there was a weak tendency for higher surface activity of $C$. volutator at night (Table 4). No daytime activities of $C$. volutator exceeded those at night, and on two nights the nocturnal activity was significantly higher than any activities found during daytime. On the mudflat, the surface activity of $H$. ulvae was significantly higher by day than by night, whereas the opposite tendency occurred for P. maculata. Inspection of the data in Table 4 does not suggest any relationship between the surface activity of invertebrates and air temperature, sediment temperature, or lunar cycle.

\section{Sediment penetrability}

On the Corophium-bed the mean sediment penetrability was $8.3 \mathrm{~cm}$ and $5.3 \mathrm{~cm}$ on the emerged areas and in the pools, respectively, whereas on the mudflat the mean values were between 4.5 and $4.9 \mathrm{~cm}(\mathrm{SE}=0.1$ and $\mathrm{n}=30$ for all values). The In-transformed data were compared using one-way ANOVA followed by a SNK-test. The sediment penetrability differed among sites $\left(\mathrm{F}_{5,174}=\right.$ $265.7, \mathrm{P}<0.001$ ), and was significantly higher on the Corophium-bed than at all sites on the mudflat $(\mathrm{P}<0.05)$. Although the penetration scores exceeded the maximum probing depth of Dunlins (about $3 \mathrm{~cm}$ corresponding to bill length), it is believed that the data show features also experienced by the birds.

\section{Discussion}

Present results suggest that during autumn migration Dunlins feed regularly at night, following the tidal cycle. However, they tend to utilize different habitats during daytime and night-time. At night, the birds congregated on the Corophium-bed, while day-feeding birds were more evenly distributed between the two transects. The available evidence regarding diurnal and nocturnal habitat use (see McNeil et al. in press) suggests increased prey availability at night as the decisive factor (Townshend et al. 1984, Roberts and McNeil 1989). In addition, reduced predation risk at night has been proposed to explain the finding that tropical shorebirds use foraging sites at night that are avoided during daytime (Roberts et al. 1989). This latter explanation can, however, be ruled out in the present study due to the proximity of the habitats. Dunlins are predominantly tactile feeders at night, this mode of feeding appearing to be less effective than visual prey detection (Evans 1986). To offset this disadvantage of tactile feeding, Dunlins should select nocturnal foraging sites that are characterized by high densities of infaunal prey in the upper sediment strata to maximize prey encounter during probing. Also, high sediment penetrability may be an important factor by reducing foraging costs when probing or by increasing the probing depth and, in turn, prey accessibility (Tjallingii 1972, Myers et al. 1980, Grant 1984, Kelsey and Hassall 1989, Mouritsen and Jensen 1992). Such conditions are achieved on the Corophium-bed where both the density and the average length of Corophium individuals occurring at or close to the sediment surface are greater at night 
than during the daytime. In addition, the sediment on the Corophium-bed is extremely soft compared with the surrounding flat. Consequently, profitable Corophium individuals are easier (or cheaper) to catch at night.

Pecking predominated in day-feeding Dunlins, whereas probing prevailed at night. Traditionally, pecking and probing have been interpreted as visual and tactile foraging, respectively. Accordingly, the Dunlins are mainly visual hunters during the daytime and tactile hunters at night, as reported for several other shorebirds, e. g. Tringa spp. (GossCustard 1970, Robert and McNeil 1989). However, to claim a direct relationship between the proportion of pecks and the degree of visual prey detection may be too simplistic. Sandpipers have high densities of both mechano- and chemoreceptors in the tip of their bill (Gerritsen and Sevenster 1985, Martin 1990), and therefore surface pecks may be attempts at both tactile prey detection and visual prey captures. The peculiar double-pecks performed only by night-feeding Dunlins could be interpreted as a tactile "search-peck" followed by prey capture. However, despite their apparent reliance on tactile searching at night, the higher pecking rate on moonlit nights compared with the dark night suggests that Dunlins take advantage of the moonlight and feed at least to some extent by sight.

Apart from fish (probably Pomatoschistus minutus), the Dunlins' diet included well known prey species (see Ehlert 1964, Bengtson and Svensson 1968, Worrall 1984, Durrell and Kelly 1990). The difference in prey items selected by Dunlins during day and night supports the idea that mode of feeding was different. The greater importance of $H$. ulvae by day than by night, and the greater importance of $C$. volutator and $N$. diversicolor on the Corophium-bed at night than during the daytime, most probably reflect the birds' use of mainly visual and tactile searching by day and night, respectively. Because $H$. ulvae individuals are active at the sediment surface by day, they must be an easy prey to birds feeding by sight. Difference in prey choice between the habitats probably reflected variation in abundance of prey. However, the greater importance of $N$. diversicolor on the mudflat compared with the Corophium-bed, regardless of higher densities on the latter, might suggest that Dunlins have a "search-image" for Corophium when feeding on the $\mathrm{Co}$ rophium-bed (sensu Goss-Custard 1977).

There are two main hypotheses explaining nocturnal foraging in shorebirds: the "supplementary hypothesis", i.e. shorebirds feed at night only when their daytime feeding has been inadequate to meet daily energy requirements, and the "preference hypothesis", i.e. shorebirds prefer to feed at night because it is more profitable (e.g. high prey availability) or safer (e.g. avoidance of diurnal predators) (see McNeil et al. in press for details and references). Since Dunlins apparently feed throughout both diurnal and nocturnal low tide periods, their foraging pattern supports the supplementary hypothesis, though it does not contradict the preference hypothesis. It seems probable that the Dunlins' nocturnal foraging be- haviour was aimed at fat depositing, in accordance with previous studies showing higher incidence of nocturnal feeding during pre-migration or migration periods (Batty 1988, Zwarts et al. 1990, Morrier and McNeil 1991). The Danish Wadden Sea is the first major stop-over area during the birds' southward migration (Smit and Wolff 1981), and refuelling of fat deposits may be necessary.

Acknowledgements - This study was supported by a grant from the Carlsberg Foundation. Special thanks to K. T. Jensen and referees for constructive comments on an earlier draft. I also thank the National Environmental Research Institute, Division of Wildlife Ecology for providing necessary equipment.

\section{References}

Batty, L. 1988. Seasonal and diurnal variations in the feeding intensity of waders on the Ria Formosa, Portugal. - Wader Study Group Bulletin 54: 9-10.

Bengtson, S.-A. and Svensson, B. 1968. Feeding habits of Calidris alpina $\mathrm{L}$. and $C$. minuta Leisl. (Aves) in relation to the distribution of marine shore invertebrates. - Oikos 19: 152157.

Boates, J. S. and Smith, P. C. 1989. Crawling behaviour of the amphipod Corophium volutator and foraging by Semipalmated Sandpipers, Calidris pusilla. - Can. J. Zool. 67: 457-462.

Burger, J. 1984. Abiotic factors affecting migrant shorebirds. In: Burger, J. and Olla, B. (eds.). Behavior of marine animals. Vol. 6. Plenum Press, New York, pp. 1-72.

Dugan, P. J. 1981. The importance of nocturnal foraging in shorebirds: a consequence of increased invertebrate prey activity. - In: Jones, N. V. and Wolff, W. J. (eds.). Feeding and survival strategies of estuarine organisms. Plenum Press, New York, pp. 251-260.

Durell, S. E. A. and Kelly, C. P. 1990. Diets of Dunlins Calidris alpina and Grey Plover Pluvialis squatarola on the Wash as determined by dropping analysis. - Bird Study 37: 44-47.

Ehlert, W. 1964. Zur Ökologie und Biologie der Ernährung einiger Limikolen-arten. - J. Orn. 105: 1-53.

Engelmoer, M., Piersma, T., Altenburg, W. and Mes, R. 1984. The Banc d'Arguin (Mauritania). - In: Evans, P. R., GossCustard, J. D. and Hale, W. G. (eds.). Coastal waders and wildfowl in winter. Cambridge University Press, Cambridge, pp. 293-310.

Evans, A. 1986. Experimental evidence for the use of visual cues by foraging Dunlins. - Wader Study Group Bulletin 48: 14-15.

- 1987. Relative availability of the prey of wading birds by day and by night. - Mar. Ecol. Prog. Ser. 37: 103-107.

Evans, P. R. 1988. Predation of intertidal fauna by shorebirds in relation to time of the day, tide and year. - In: Chelazzi, G. and Vannini, M. (eds.). Behavioral adaptation to intertidal life. Plenum Press, New York, pp. 65-78.

Gerritsen, A. F. C. and Sevenster, J. G. 1985. Foraging behaviour and bill anatomy in sandpipers. - Fortsch. Zool. 30: 237-239.

Goss-Custard, J. D. 1969. The winter feeding ecology of the Redshank Tringa totanus. - Ibis 111: 338-356.

- 1970. Feeding dispersion in some overwintering wading birds. - In: Crook, J. H. (ed.). Social behaviour in birds and mammals. Academic Press, London, pp. 3-35.

- 1977. The energetics of prey selection by Redshank (Tringa totanus (L.)) in relation to prey density. - J. Anim. Ecol. 46: $1-19$.

- 1984. Intake rates and food supply in migrating and wintering shorebirds. - In: Burger, J. and Olla, B. (eds.). Behavior 
of marine animals. Vol. 6. Plenum Press, New York, pp. 233-270.

Grant, J. 1984. Sediment microtopography and shorebird foraging. - Mar. Ecol. Prog. Ser. 19: 293-296.

Heppleston, P. B. 1971. The feeding ecology of Oystercatchers Haematopus ostralegus L. in winter in northern Scotland. J. Anim. Ecol. 41: 651-672.

Hulscher, J. B. 1976. Localization of cockles (Cardium edule L.) by the Oystercatcher (Haematopus ostralegus L.) in darkness and daylight. - Ardea 64: 292-310.

Kelsey, M. G. and Hassall, M. 1989. Patch selection by Dunlin on a heterogeneous mudflat. - Ornis Scand. 20: 250-254.

Laursen, K. and Frikke, J. 1984. The Danish Wadden Sea. - In: Evans, P. R., Goss-Custard, J. D. and Hale, W. G. (eds.). Coastal waders and wildfowl in winter. Cambridge University Press, Cambridge, pp. 214-223.

Manseau, M. and Ferron, J. 1991. Activité alimentaire nocturne des Bécasseaux semipalmés (Calidris pusilla) lors d'une halte migratoire dans la Baie de Fundy. - Can J. Zool. 69: 380-384.

Martin, G. 1990. Birds by night. - Poyser, London.

McNeil, R. and Robert, M. 1988. Nocturnal feeding strategies of some shorebird species in a tropical environment. - Acta 19th Int. Orn. Congr.: 2328-2336.

- , Drapeau, P. and Goss-Custard, J. D. In press. The occurrence and adaptive significance of nocturnal habits in waterfowl. - Biol. Rev.

Morrier, A. and McNeil, R. 1991. Time-activity budget of Wilson's and Semipalmated Plovers in a tropical environment. Wilson Bull. 103: 598-620.

Mouritsen, K. N. 1991. Diurnal and nocturnal foraging behaviour in Dunlins Calidris alpina. - Thesis, Univ. of Aarhus.

- and Jensen, K. T. 1992. Choice of microhabitat in foraging Dunlins Calidris alpina: the importance of sediment penetrability. - Mar. Ecol. Prog. Ser. 85: 1-8.

Myers, J. P., Williams, S. L. and Pitelka, F. A. 1980. An experimental analysis of prey availability for Sanderlings (Aves: Scolopacidae) feeding on sandy beach crustaceans. - Can. J. Zool. 58: 1564-1574.

Pienkowski, M. W. 1981. How foraging plovers cope with environmental effects on invertebrate behaviour and availability. - In: Jones, N. V. and Wolff, W. J. (eds.). Feeding strategies and survival of estuarine organisms. Plenum Press, New York, pp. 179-192.

- 1982. Diet and energy intake of Grey and Ringed Plovers, Pluvialis squatarola and Charadrius hiaticula, in the nonbreeding season. - J. Zool., Lond. 197: 511-549.

- 1983. Changes in the foraging pattern of plovers in relation to environmental factors. - Anim. Behav. 31: 244-264.

Puttick, G. M. 1984. Foraging and activity patterns in wintering shorebirds. - In: Burger, J. and Olla, B. (eds.). Behavior of marine animals. Vol. 6. Plenum Press, New York, pp. 203231.

Reise, K. 1978. Experiments on epibenthic predation in the Wadden Sea. - Helgoländer wiss. Meeresunters. 31: 55-101.

Robert, M. and McNeil, R. 1989. Comparative day and night feeding strategies of shorebirds species in a tropical environment. - Ibis 131: 69-79.

- , McNeil, R. and Leduc, A. 1989. Conditions and significance of night feeding in shorebirds and other water birds in a tropical lagoon. - Auk 106: 94-101.

Smit, C. J. and Wolff, W. J. 1981. Birds of the Wadden Sea. Balkema. Rotterdam.

Tjallingii, S. J. 1972. Habitat selection of the avocet (Recurvirostra avocetta) in relation to feeding. - Proc. XV Int. Orn. Congr.: 696-697.

Townshend, D. J., Dugan, P. J. and Pienkowski, M. W. 1984. The unsociable plover - use of intertidal areas by Grey Plovers. - In: Evans, P. R., Goss-Custard, J. D. and Hale, W. G. (eds.) Coastal waders and wildfowl in winter. Cambridge University Press, Cambridge, pp. 140-159.

Worrall, D. H. 1984. Diet of the Dunlin Calidris alpina in the Severn Estuary. - Bird Study 31: 203-212.

Zwarts, L., Blomert, A.-M. and Hupkes, R. 1990. Increase of feeding time in waders preparing for spring migration from the Banc d'Arguin, Mauritania. - Ardea 78: 237-256.

(Received 5 October 1992, revised 22 March 1993, accepted 29 March 1993.) 
http://www.jstor.org

\section{LINKED CITATIONS \\ - Page 1 of 1 -}

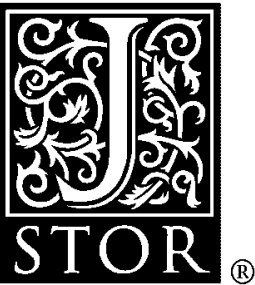

You have printed the following article:

Day and Night Feeding in Dunlins Calidris alpina: Choice of Habitat, Foraging Technique and Prey

K. N. Mouritsen

Journal of Avian Biology, Vol. 25, No. 1. (Mar., 1994), pp. 55-62.

Stable URL:

http://links.jstor.org/sici?sici=0908-8857\%28199403\%2925\%3A1\%3C55\%3ADANFID\%3E2.0.CO\%3B2-V

This article references the following linked citations. If you are trying to access articles from an off-campus location, you may be required to first logon via your library web site to access JSTOR. Please visit your library's website or contact a librarian to learn about options for remote access to JSTOR.

\section{References}

Feeding Habits of Calidris alpina L. and C. minuta Leisl. (Aves) in Relation to the Distribution of Marine Shore Invertebrates

Sven-Axel Bengtson; Bo Svensson

Oikos, Vol. 19, No. 1. (1968), pp. 152-157.

Stable URL:

http://links.jstor.org/sici?sici=0030-1299\%281968\%2919\%3A1\%3C152\%3AFHOCAL\%3E2.0.CO\%3B2-U

The Energetics of Prey Selection by Redshank, Tringa totanus (L.), in Relation to Prey Density

J. D. Goss-Custard

The Journal of Animal Ecology, Vol. 46, No. 1. (Feb., 1977), pp. 1-19.

Stable URL:

http://links.jstor.org/sici?sici=0021-8790\%28197702\%2946\%3A1\%3C1\%3ATEOPSB\%3E2.0.CO\%3B2-N

The Feeding Ecology of Oystercatchers (Haematopus ostralegus L.) in Winter in Northern Scotland

P. B. Heppleston

The Journal of Animal Ecology, Vol. 40, No. 3. (Oct., 1971), pp. 651-672.

Stable URL:

http://links.jstor.org/sici?sici=0021-8790\%28197110\%2940\%3A3\%3C651\%3ATFEOO\%28\%3E2.0.CO\%3B2-5 